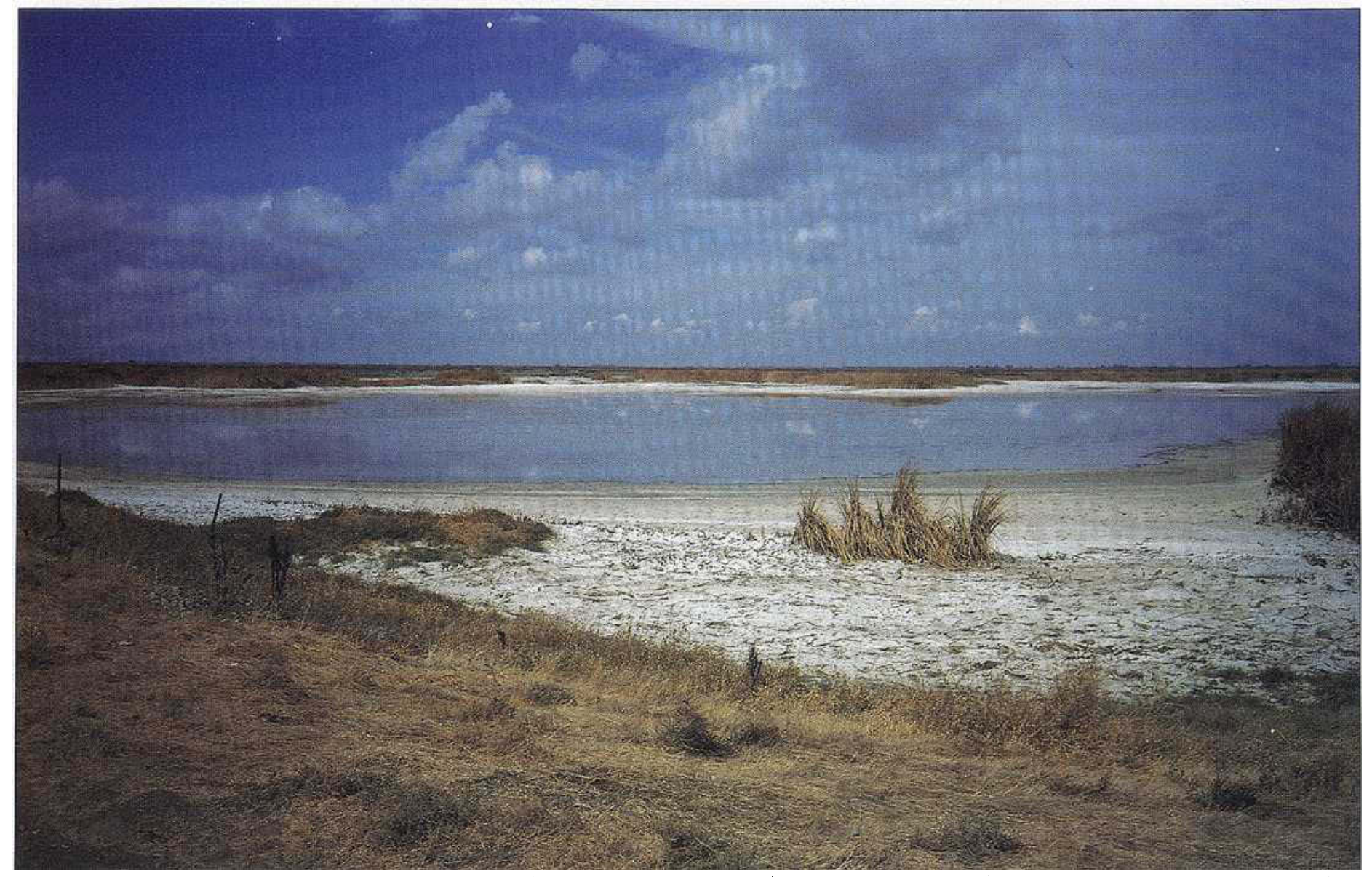

Former holding area for westside drainwater.

Poor soil-water infiltration in the eastside of the San Joaquin Valley is frequently attributed to low-salinity irrigation water. This report assesses the feasibility of improving infiltration rates by blending the more saline westside drainwater with the less saline FriantKern Canal water, a strategy which would also provide a disposal method for westside drain water. However, the study found that boron and molybdenum concentrations in the drainwaters require large blending ratios to prevent crop yield reductions of tree crops grown along the eastside. These large blending ratios mean that the blended irrigation water may have little effect on improving filtration.

\title{
Trace elements limit potential for blending San Joaquin drainwater with canal water
}

\author{
Blaine R. Hanson $\square$ Wilbur Bowers $\square$ Stephen R. Grattan \\ Donald W. Grimes $\square$ Kenneth K. Tanji
}

Poor soil-water infiltration affects about 530,000 acresin theeastside of the San Joaquin Valley, including large acreages in Fresno, Kings, Madera, and Tulare Counties. The poor infiltration in this region is frequently attributed to low electrolyte or very lowsalinity irrigation water used along the eastside. The electrical conductivity (EC) or salt concentration of the Friant-Kern Canal water, used for eastside irrigation, is about 0.05 decisiemens per meter $(\mathrm{dS} / \mathrm{m})$, approaching that of distilled water. In addition to low saline water, hardpans, compaction from cultural operations, and crusting may also be partly responsible.

Numerous studies have shown that relationships exist between (1) the hydraulic conductivity (and infiltration rate) of a soil and (2) the electrical conductivity and sodiumabsorption ratio(SAR) of theinfiltrating water. Generally, as the EC of the infiltrating water increases, the hydraulic conductivity of the soil increases for a given SAR. But as the sodium absorption ratio increases, the soil-waterinfiltration ratedecreases at a given salinity. This is because sodium - as distinct from most salts - causes soil particles to come apart, breaking down the soil structure essential to infiltration. In the eastside of theSan Joaquin Valley, where many of the soils are classified as sandy loams and fine sandy loams, the primary mechanisms for these events are shrinking and swelling of clay particles, and clay dispersion. 
One strategy proposed for improving infiltration rates is to blend westside subsurface drainwater with the canal water to increase the salinity of the irrigation water. This strategy would also help dispose of the drainwater. The purpose of this study is to assess the feasibility of this method.

\section{Factors limiting blending ratios}

Factors limiting the blending of westside drainwater with Friant-Kern Canal water include:

- Effect of salinity of blended water on yield of eastside crops.

- Effect of trace elements on crop yield and quality.

- Effect of blended water on soil-water infiltration and soil chemical quality.

- Effect of blended water on eastside groundwater quality.

Major crops grown along the eastside of the valley include vines, trees crops (fruits, nuts, citrus), field and row crops, and forage crops such as alfalfa. To avoid yield reduction, the EC of the blended water must not exceed $1 \mathrm{dS} / \mathrm{m}$ for the more salt sensitive eastside crops (table 1 ).

Concentrations of elements harmful to plants, primarily boron, chloride, and sodium, may also limit the amount of blending, particularly for irrigation of trees and vines. Maximum recommended boron

\section{Equations used to calculate} blending ratios

$$
\mathrm{C}_{\mathrm{b}}\left(\mathrm{V}_{\mathrm{c}}+\mathrm{V}_{\mathrm{d}}\right)=\mathrm{C}_{\mathrm{d}} \mathrm{V}_{\mathrm{d}}+\mathrm{C}_{\mathrm{c}} \mathrm{V}_{\mathrm{c}}
$$

where:

$\mathrm{C}_{\mathrm{b}}=$ maximum element concentration or EC of blended water without a yield loss $\mathrm{C}_{\mathrm{d}}=$ element concentration or $\mathrm{EC}$ of drainwater

$\mathrm{V}_{\mathrm{d}}=$ volume of drainwater used,

$C_{C}=$ element concentration or $E C$ of canal water,

$\mathrm{V}_{\mathrm{C}}=$ volume of irrigation water used.

By manipulating the above equation, the blending ratio $\left(V_{C} / V_{d}\right)$ can also be calculated using the following relationship:

$$
\frac{v_{c}}{v_{d}}=\frac{C_{d}-C_{b}}{c_{b}-c_{c}}
$$

where $C_{b}$ is the maximum concentration or EC tolerated by a crop.

A unit volume of drainwater is assumed and the equation is solved for the volume of irrigation water needed per unit of drainwater for each constituent of concern. These volumes are used to give the blending ratio $\left(V_{C}\right)$ $V_{d}$ ). The constituent that produces the highest blending ratio is the most limiting element. concentration in soil water tolerated by some of the eastside crops is reported in table 1. Since fruit yields of trees and vines could be reduced with a continued use of irrigation water containing excessive boron, the maximum recommended boron concentration of irrigation water is about 0.5 milligrams per liter $(\mathrm{mg} / \mathrm{L})$. However, the relationship between the concentration of boron in the soil water and that in the irrigation water is uncertain.

In addition to boron toxicity, chloride is also detrimental to sensitive eastside crops. Chloride concentrations in excess of 6.7 to 16.6 milliequivalents per liter (meq/L) can cause leaf injury in tree crops.

Certain trace elements, such as selenium and molybdenum, can damageforagecrops. Selenium toxicity and molybdous can develop in grazing animals if selenium and molydenum are excessive in the forage tissue. A maximum irrigation water concentration of $0.01 \mathrm{mg} / \mathrm{L}$ is recommended for molybdenum. Certain trace elements such as uranium and vanadium found in many evaporation ponds at extremely high concentrations, may further limit the amount of drainwater that can be blended.

\section{Maximum allowable blending ratios}

Table 2 shows water quality data for the Friant-Kern Canal and for the subsurface drainage systems monitored by the State Department of Water Resources in 1986. The average EC of the canal water was approximately $0.05 \mathrm{dS} / \mathrm{m}$, whereas the SAR was about 0.6 . In contrast, the average $\mathrm{EC}$ of the drainwater ranges from about $6.8 \mathrm{dS} / \mathrm{m}$. in central drains to $21.3 \mathrm{dS} / \mathrm{m}$ in southern drains. SARs range from nearly 11 to 44 (meq/L)1/2.

The dominant cation in the drainwater is sodium, and sulfate is the dominant anion. In addition, a number of trace elements in the drainwater may be toxic to plants (boron) or animals (boron, selenium, and molybdenum). Because of large differences in the concenrations of these elements, separate evaluations were made for drainwater from the central area (Dos Palos to Mendota) and the southern area (northern part of Kings County to south of Bakersfield)

Blending ratios [volume of Friant-Kern canal water/volume of drainwater] $\left(\mathrm{V}_{\mathrm{c} /} \mathrm{V}_{\mathrm{d}}\right)$ were determined for the soluble salts and trace elements in the drainwater for which water quality criteria exist (table 1 ). The volume of drainwater that can be blended with a given volume of irrigation water to achieve the maximum allowable concentration was mathematically estimated (see sidebar.)

\section{Results}

The results of these calculations revealed that salinity was not the limiting factor for blending. Blending ratios based on salinity constraints ranged from 6 to 21 (table 3). Instead, the limiting factors were boron for the central subsurface drains and molybdenum for the southern subsurface drains.

Table 3 shows the maximum allowable values of boron and molybdenum and the blending ratios needed to achieve these values. For the central drains, a ratio of nearly 25 (25 acre-feet of Friant-Kern water to 1 acrefoot of drain water) is needed to obtain a boron concentration of $0.5 \mathrm{mg} / \mathrm{L}$ in the blended water. The ratio for boron is nearly 46:1 for the southern drains. However, because of the molybdenum concentrations of those drains, a ratio of about 104:1 is needed to achieve a molybdenum concentration of $0.01 \mathrm{mg} / \mathrm{L}$. If, however, only drainage water with molybdenum concentrations of $1 \mathrm{mg} /$ $\mathrm{L}$ or less is used, the ratio drops to $37: 1$, and boron becomes the limiting factor.

\section{Discussion}

The calculated ECandSAR of the blended waters using maximum allowable blending ratios, where the limiting factor is either salinity (EC), boron, or molybdenum, are shown in table 4 . Both of these water quality characteristics are used to predict soil water infiltration problems associated with water quality.

If salinity is the limiting factor, the relationship in figure 1 shows a slight potential of improving soil infiltration with blended water. However, because blending ratios are controlled by boron or molybdenum, the salinity of the blended water remains relatively low because of the large required dilutions. Figure 1 shows that this blended water may cause a slight to moderate increase in the infiltration rate.

This analysis suggests that blending drainage water with canal water may have a slight effect on improving infiltration rates.

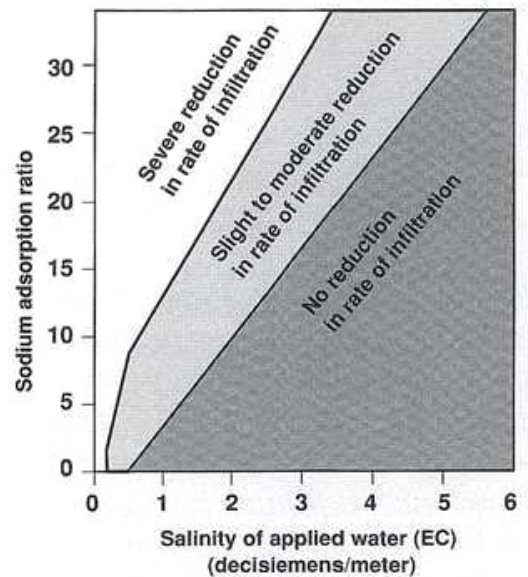

Fig. 1. The effect of water quality on infiltration rate can be calculated by charting the intersection of the water's salinity with its sodium absorption ratio. (Ayers, R.S. and D.W. Westcot. 1985. Water Quality for Agriculture. Food and Agriculture Organization Irrigation and Drainage Paper 29 [rev 1]. 174p.) 
With boron as the limiting factor, the ratios result in water too low in salinity to substantially improve infiltration. However, we recognize that some subjective judgments were made in developing the guidelines in figure 1. A more precise assessment of the effect of the blended water on infiltration may require field studies.

While selenium is not a limiting factor for crop production, the long-term use of blended water may affect the accumulation of selenium in edible tissue. We therefore assessed the domestic water quality of the blended water. Weighted selenium concentrations were 107 and 74 micrograms per liter $(\mu \mathrm{g} / \mathrm{L})$ for the central and southern drains, respectively. When blended at the ratios needed to limit boron concentrations, selenium concentrations were about $12 \mu \mathrm{g} /$ $\mathrm{L}$, slightly higher than the current EPA standard of $10 \mu \mathrm{g} / \mathrm{L}$ for drinking water. Other trace elements, such as uranium and vana-

\begin{tabular}{|c|c|c|c|}
\hline Crop & Acreage ${ }^{\star}$ & $E C_{i} t$ & $\begin{array}{c}\text { Boron } \\
\text { concentration } \neq\end{array}$ \\
\hline & & & $m g / L$ \\
\hline Barley & 27,000 & 5.3 & $0.75-1.0$ \\
\hline Beans & 17,000 & 0.7 & $0.75-1.0$ \\
\hline Born (grain) & 6,800 & 1.1 & $2.0-4.0$ \\
\hline Corn (silage) & 12,200 & 1.2 & $2.0-4.0$ \\
\hline Cotton & 427,000 & 5.1 & $6.0-15.0$ \\
\hline Alfalfa hay & 80,000 & 1.3 & $4.0-6.0$ \\
\hline Irrigated pasture & 50,000 & 1.0 & - \\
\hline Sugar beets & 27,400 & 4.7 & $4.0-6.0$ \\
\hline Wheat & 43,000 & 4.0 & $0.75-1.0$ \\
\hline Cantaloupe & 34,500 & - & $2.0-4.0$ \\
\hline $\begin{array}{l}\text { Tomatoes } \\
\text { (processed) }\end{array}$ & 64,800 & 1.7 & $4.0-6.0$ \\
\hline Almonds & 30,667 & 1.0 & - \\
\hline Lemons & 1,019 & - & $<0.5$ \\
\hline Oranges & 19,656 & 1.1 & $0.5-0.75$ \\
\hline Grapes & 208,442 & 1.0 & $0.3-0.75$ \\
\hline Nectarines & 12,764 & - & - \\
\hline Peaches & 13,046 & 1.1 & $0.3-0.5$ \\
\hline Plums & 17,740 & 1.0 & $0.3-0.5$ \\
\hline
\end{tabular}

* Data from Fresno County Agricultural Commissioner, 1988.

t Maximum EC of irrigation water with no yield reductions. We assume that this quality of irrigation water does not change over time, and the leaching fraction is $15 \%$

¥ Maximum concentrations tolerated in irrigation water without yield or growth reductions.

TABLE 2. Water quality of Friant-Kern Canal water and subsurface drainwater

\begin{tabular}{lcccc}
\hline & EC & SAR & Boron & Molybdenum \\
\hline \hline \multirow{2}{*}{ Canal } & $d S / M$ & & $\mathrm{mg} / \mathrm{L}$ & $\mathrm{mg} / \mathrm{L}$ \\
Central drains & 0.05 & 0.6 & $<0.15$ & $<0.10$ \\
Southern drains & 6.8 & 10 & 12 & 0.03 \\
\hline
\end{tabular}

TABLE 3. Calculated maximum allowable blending ratios (volume of canal water/volume of drainwater) needed to avoid crop yield loss and to maintain the concentration of molybdenum within water quality

standards

\begin{tabular}{lcccc}
\hline \hline Limiting & Maximum & \multicolumn{3}{c}{ Ratios } \\
\cline { 3 - 4 } factor & value & Central & Southern \\
\hline EC & $1.0 \mathrm{dS} / \mathrm{m}$ & 6.1 & 21.4 \\
Boron & $0.5 \mathrm{mg} / \mathrm{L}$ & 25.5 & 46.4 \\
Molybdenum & $0.01 \mathrm{mg} / \mathrm{L}$ & 2.9 & $104(37)^{*}$
\end{tabular}

Number in parentheses is ratio for drainwater that contains less than $1 \mathrm{mg} / \mathrm{L}$ molybdenum.

TABLE 4. EC and SAR of blended water using maximum allowable blending ratios where the limiting factor is either EC, boron, or molybdenum

\begin{tabular}{lcccc}
\hline \hline Limiting & \multicolumn{2}{c}{ Central } & \multicolumn{2}{c}{ Southern } \\
\cline { 2 - 5 } Factor & EC & SAR & EC & SAR \\
\hline & $d S / M$ & & $d S / M$ & 2.5 \\
EC & 1.0 & 2.0 & 1.0 & 1.1 \\
Boron & 0.30 & 0.8 & 0.50 & $1.01(1.7)^{*}$ \\
Molybdenum & 1.78 & 3.2 & $0.25(0.61)^{*}$ & \\
\hline
\end{tabular}

Drainwater with less than $1 \mathrm{mg} / \mathrm{L}$ molybdenum.

dium, may also exist in high enough concentrations to further increase the blending ratio.

We assessed the impact of the blending process on groundwater quality by estimating the concentrations of deep percolation for leaching factions of $5 \%$ and $15 \%$. This analysis assumed long-term steady-state leaching. Results for using drainwater of the southern drains showed a selenium concentration of $240 \mu \mathrm{g} / \mathrm{L}$ and $80 \mu \mathrm{g} / \mathrm{L}$ for leaching fractions of $5 \%$ and $15 \%$, respectively, which greatly exceeds the EPA standard. EC was 3.8 and $1.3 \mathrm{dS} / \mathrm{m}$, and boron was 6 and $2 \mathrm{mg} / \mathrm{L}$, for $5 \%$ and $15 \%$ leaching, respectively. In reality, it is difficult to predict the long-term effect of this deep percolation on groundwater quality because of rainfall and regional flows.

\section{Conclusions}

We conclude the following:

- In the eastside of the San Joaquin Valley, some major crops (having substantial economic value) are sensitive to salinity and boron. Major forage crops are sensitive to molybdenum. Maximum concentrations that can be tolerated by these crops were 0.5 $\mathrm{mg} / \mathrm{L}$ for boron and $0.01 \mathrm{mg} / \mathrm{L}$ for molybdenum. EC was limited to a maximum of 1 $\mathrm{dS} / \mathrm{m}$.

- The limiting factor controlling blending ratios (volume of canal water to volume of drainwater) was the concentration of boron in drainwater from the central area, and molybdenum concentrations in drainwater from the southern area. If drainwater usage is limited to molydenum concentrationsless than $1 \mathrm{mg} / \mathrm{L}$, then boron was limiting in the southern area.

- Because boron is the limiting factor, blending ratios of 25.5 and 46.4 are needed for the central and southern areas, respectively. These large ratios are necessary to limit the boron concentration to $0.5 \mathrm{mg} / \mathrm{L}$ in the blended water.

- Because of the large dilutions required to maintain low boron levels, we calculate the salinity of the blended water is less than 0.3 to $0.5 \mathrm{dS} / \mathrm{m}$. This level of salinity may slightly or moderately improve infiltration rates. Field testing will be needed to establish the actual effect.

- Long-term effects of blending on trace element accumulation in soil, and on plant uptake of trace elements, are unknown.

- Blending could have an adverse longterm impact on domestic use of either surface water or groundwater.

Blaine R. Hanson is Irrigation and Drainage Specialist, Wilbur Bowers is Post-Graduate Researcher, Stephen R. Grattan is Plant-Water Relations Specialist, Donald W. Grimes is Water Scientist and Kenneth K. Tanji is Professor, Department of Land, Air and Water Resources, UC Davis. 